\title{
Mode of action of membrane-disruptive lytic compounds from the marine dinoflagellate Alexandrium tamarense
}

\author{
Haiyan Ma, Bernd Krock, Urban Tillmann, Ulf Bickmeyer, Martin Graeve, Allan Cembella* \\ Alfred Wegener Institute for Polar and Marine Research, Am Handelshafen 12, 27570 Bremerhaven, Germany
}

\section{A R T I C L E I N F O}

\section{Article history:}

Received 8 December 2010

Received in revised form 9 May 2011

Accepted 9 June 2011

Available online 30 June 2011

\section{Keywords:}

Dinoflagellate

Alexandrium tamarense

Cell lysis

Allelopathy

Plasma membrane

Sterol

\begin{abstract}
A B S T R A C T
Certain allelochemicals of the marine dinoflagellate Alexandrium tamarense cause lysis of a broad spectrum of target protist cells but the lytic mechanism is poorly defined. We first hypothesized that membrane sterols serve as molecular targets of these lytic compounds, and that differences in sterol composition among donor and target cells may cause insensitivity of Alexandrium and sensitivity of targets to lytic compounds. We investigated $\mathrm{Ca}^{2+}$ influx after application of lytic fractions to a model cell line PC12 derived from a pheochromocytoma of the rat adrenal medulla to establish how the lytic compounds affect ion flux associated with lysis of target membranes. The lytic compounds increased permeability of the cell membrane for $\mathrm{Ca}^{2+}$ ions even during blockade of $\mathrm{Ca}^{2+}$ channels with cadmium. Results of a liposome assay suggested that the lytic compounds did not lyse such target membranes non-specifically by means of detergent-like activity. Analysis of sterol composition of isolates of $A$. tamarense and of five target protistan species showed that both lytic and non-lytic A. tamarense strains contain cholesterol and dinosterol as major sterols, whereas none of the other tested species contain dinosterol. Adding sterols and phosphatidylcholine to a lysis bioassay with the cryptophyte Rhodomonas salina for evaluation of competitive binding indicated that the lytic compounds possessed apparent high affinity for free sterols and phosphatidylcholine. Lysis of protistan target cells was dose-dependently reduced by adding various sterols or phosphatidylcholine. For three tested sterols, the lytic compounds showed highest affinity towards cholesterol followed by ergosterol and brassicasterol. Cholesterol comprised a higher percentage of total sterols in plasma membrane fractions of $A$. tamarense than in corresponding whole cell fractions. We conclude therefore that although the molecular targets of the lytic compounds are likely to involve sterol components of membranes, $A$. tamarense must have a complex selfprotective mechanism that still needs to be addressed.
\end{abstract}

(c) 2011 Elsevier Ltd. All rights reserved.

\section{Introduction}

Marine dinoflagellates of the genus Alexandrium are known to produce secondary metabolites with widespread allelochemical effects on other photosynthetic (Blanco and Campos, 1988; Arzul et al., 1999; Fistarol et al., 2004; Tillmann et al., 2007, 2008a; Tillmann and Hansen, 2009)

\footnotetext{
* Corresponding author. Tel.: +49 47148311494; fax: +49 47148312115. E-mail address: allan.cembella@awi.de (A. Cembella).
}

as well as heterotrophic protists (Hansen, 1989; Hansen et al., 1992; Tillmann and John, 2002; Tillmann et al., 2007, 2008a). Cell lysis is the most common reaction of target species when exposed to Alexandrium cell cultures, cell-free culture supernatant or filtrate (Tillmann et al., 2008b; Ma et al., 2009). The unknown allelochemicals from Alexandrium are therefore assumed to act destructively on the external plasma membrane of sensitive organisms.

The exact molecular composition of cell plasma membranes in eukaryotes varies widely among species. Nevertheless, because they share commonalities in structure 


\begin{tabular}{ll}
\hline Nomenclature \\
ATP & Adenosine-5'-triphosphate \\
ATPase & Adenosine triphosphatase \\
BCA & Bicinchoninic acid \\
CCD & Charge-coupled device \\
DSP & Diarrhetic shellfish poisoning \\
EDTA & Ethylenediaminetetraacetic acid \\
EGTA & Ethylene glycol bis-(2-aminoethyl ether)- \\
& N,N,N',N'-tetraacetic acid \\
GC-MS & Gas chromatography-Mass spectrometry \\
HEPES & 4-(2-hydroxyethyl)-1- \\
& piperazineethanesulfonic acid \\
HILIC & Hydrophilic interaction ion-chromatography \\
MES & 2-(N-morpholino) ethanesulfonic acid \\
OA & Okadaic acid \\
PC & Phosphatidylcholine \\
PEG & Polyethylene glycol \\
RPMI & Roswell Park Memorial Institute medium \\
SPE & Solid phase extraction \\
ZIC-HILIC Zwitterionic-HILIC
\end{tabular}

and function according to recent models (Mayor and Rao, 2004), the membranes typically comprise similar general classes of metabolites, including phospholipids, sterols, transmembrane proteins, polysaccharides, etc. In many cases, however, it is still unknown how lytic compounds interact with the membrane of target cells and how the producing organisms protect their own membranes from destructive attack.

Research on membrane-lysing toxins isolated from microorganisms has been carried out for decades. For example, polyene antibiotics amphotericin $\mathrm{B}(\mathrm{AmB})$ and filipin are known to interact with sterols in biomembranes when lysing target cells, but they permeate the membrane by different mechanisms (Kotlerbrajtburg et al., 1979; Brajtburg et al., 1980; Knopik-Skrocka and Bielawski, 2002). Eight pairs of AmB/sterols comprise a complex similar to ion-channels in the membrane (Andreoli, 1974; de Kruijf and Demel, 1974), whereas filipin induces damage by large non-selective perforations thereby causing membrane disruption (Knopik-Skrocka and Bielawski, 2002). Selective toxicity of AmB is due to higher affinity for ergosterol than cholesterol, the principal fungal and mammalian plasma membrane sterols, respectively.

Marine dinoflagellates, including toxic species, are known for the production of unusual sterols, particularly 4$\alpha$-methyl derivatives such as gymnodinosterol and brevesterol (Giner et al., 2003), with poorly defined or unknown function. Furthermore, several studies on membrane permeation mechanisms of hemolytic and/or lytic polyene-polyhydroxy toxins from dinoflagellates are also reported to relate to membrane sterols. Hemolytic activity of amphidinols isolated from the dinoflagellate Amphidinium klebsii is apparently increased when cholesterol is present in the target membrane (Paul et al., 1996, 1997; Morsy et al., 2008a). Karlotoxins (KmTx) from the dinoflagellate Karlodinium veneficum show different binding affinities to conspecific sterols than to sterols of target species, indicating that the toxin producers may protect themselves by possessing special sterols, e.g. the 4$\alpha$-methyl sterol gymnodinosterol, which does not interact with the toxins (Deeds and Place, 2006).

Lytic compounds released by Alexandrium tamarense show functional if not structural similarities to the dinoflagellate polyene metabolites amphidinols and karlotoxins with respect to their effects on cell membranes. The membrane-active compounds from $A$. tamarense lyse membranes of sensitive protists, but microscopic observations have revealed no effect on cells of various strains of $A$. tamarense, of other species of the genus Alexandrium, or of the toxigenic prymnesiophyte Prymnesium parvum (Tillmann et al., 2007). Several studies on sterol composition of Alexandrium spp. have shown that the 4-methyl sterol dinosterol is one of the major components (Piretti et al., 1997; Leblond and Chapman, 2002). Similar to gymnodinosterol found in Karlodinium, certain specific sterols might protect membranes of $A$. tamarense cells from being lysed by their own lytic compounds. Given previous research on membrane-lytic activity in marine dinoflagellates, our study of the lytic activity of $A$. tamarense was designed accordingly to establish: (1) if cell lysis in target species is directly caused by membrane disruption; (2) if the mechanism of cell lysis is non-specific (e.g., "detergentlike"); (3) if the lytic compounds also interact with sterols; (4) if Alexandrium cells protect themselves by possessing special sterols; and (5) if the target protists have sterols with high affinity to the lytic compounds.

We therefore investigated the cytotoxicity of lytic compounds from A. tamarense on rat neuroendocrine PC12 cells, and determined an increased permeability of target cell membranes for $\mathrm{Ca}^{2+}$ ions despite blockade of $\mathrm{Ca}$ channels, possibly by membrane disruption. Nevertheless, supernatant fractions from Alexandrium with lytic activity against the cryptophyte Rhodomonas did not lyse liposome membranes non-specifically, as would be expected for detergent-like activity. We also compared the whole cell as well as plasma membrane sterol composition of $A$. tamarense strains with those of five target strains of protists. Although sterols, specifically cholesterol, appear to be a molecular target of the lytic substances against liposomes, we propose that the lytic effects against protist cells cannot be accounted for merely by compositional variation and relative binding affinity among various sterol analogs.

\section{Materials and methods}

\subsection{Protist culture}

Two clones of $A$. tamarense (Alex2 and Alex5) were selected based on their different lytic capacity as quantified by a whole cell cryptophyte Rhodomonas bioassay (Tillmann et al., 2009). Alex2 had high lytic capacity whereas Alex5 had no measurable lytic effect on Rhodomonas and thus served as a negative control. Both Alexandrium strains were isolated from the North Sea coast of Scotland (Tillmann et al., 2009) and grown in K-medium (Keller et al., 1987), supplemented with selenite (Dahl et al., 1989), prepared from $0.2 \mu \mathrm{m}$ sterile-filtered (VacuCap, Pall Life Sciences, Dreieich, Germany) North Sea seawater (salinity 32 psu). Cultures 
were maintained in $1 \mathrm{~L}$ Erlenmeyer flasks under controlled conditions at $15{ }^{\circ} \mathrm{C}$ under cool-white fluorescent light at a photon flux density (PFD) of $100 \mu \mathrm{mol}$ photons $\mathrm{m}^{-2} \mathrm{~s}^{-1}$ on a $16 \mathrm{~h}$ light: $8 \mathrm{~h}$ dark photocycle.

Five protist species were selected for target sensitivity experiments. The autotrophic cryptophyte Rhodomonas salina (Kalmar Culture Collection KAC 30), the chlorophyte Dunaliella salina (AWI culture collection), and the raphidophyte Heterosigma akashiwo (CCMP 2274) were cultured under the same conditions as A.tamarense. The heterotrophic dinoflagellates Oxyrrhis marina (Göttingen culture collection, strain B21.89) and Gyrodinium dominans (AWI culture collection) were grown at $20^{\circ} \mathrm{C}$ under cool-white fluorescent light at a PFD of $20 \mu \mathrm{mol}$ photons $\mathrm{m}^{-2} \mathrm{~s}^{-1}$ on a $16 \mathrm{~h}$ light: $8 \mathrm{~h}$ dark photocycle, with the chlorophyte $D$. salina as food. Cultures were starved and free of food algal cells (as checked by microscopy) before harvested for sterol analysis.

\subsection{Determination of lytic compound targets with PC12 cells}

\subsubsection{Cell culture methods}

PC12 cells derived from a pheochromocytoma of the rat adrenal medulla were obtained from the CLS (Cell Line Service, Eppelheim, Germany and German Collection of Microorganisms and Cell Cultures) and kept in culture medium containing RPMI 1640, 10\% fetal calf serum, 5\% horse serum. Cells were cultivated in an incubator at $37^{\circ} \mathrm{C}$, $90 \%$ humidity and $5 \% \mathrm{CO}_{2}$ with regular medium changes twice a week or when additionally necessary. Cells were grown in culture flasks and 1-2 days prior to the experiments were seeded into Petri dishes coated with collagen.

\subsubsection{Preparation of lytic fractions}

Supernatant fractions obtained by solid phase extraction (SPE) in $80 \%$ methanol and hydrophilic interaction ionchromatography (HILIC) fractions were prepared from $A$. tamarense cell cultures of Alex 2 and Alex5 in stationary growth phase, as previously described (Ma et al., 2009). In the current experiment, Alex 5 fractions served as a negative control to ensure that any observed effect was induced by the allelochemicals from Alex 2 fractions rather than by artifacts. For HILIC fractions, $50 \mu \mathrm{L}$ SPE fraction, purified from approximately $600 \mathrm{~mL}$ supernatant, was separated through an analytical column $(150 \times 4.6 \mathrm{~mm})$ packed with $5 \mu \mathrm{m}$ ZIC-HILIC, $200 \AA$ A, (SeQuant, Haltern, Germany) and maintained at $25^{\circ} \mathrm{C}$. A pre-column with the same packing material was also used. The flow rate was $0.7 \mathrm{~mL} \mathrm{~min}^{-1}$ and gradient elution was performed with two eluants. Eluant $\mathrm{A}$ was $2 \mathrm{mM}$ formic acid and $5 \mathrm{mM}$ ammonium formate in $20 \%$ water and $80 \%$ acetonitrile; eluant B was $10 \mathrm{mM}$ formic acid and $10 \mathrm{mM}$ ammonium formate in water. The gradient was as follows: column equilibration with $0 \%$ eluant $\mathrm{B}$ until 20 min, then linear gradient to $100 \%$ B until $35 \mathrm{~min}$, followed by isocratic elution with $100 \%$ eluant B until 45 min and finally a return to initial $0 \%$ eluant B until $46 \mathrm{~min}$. A total of five runs was performed and fraction components with retention times of 7-9 min (according to preliminary results, data not shown) were collected. The fractions were pooled and dried under $\mathrm{N}_{2}$, and finally dissolved in $1 \mathrm{~mL} \mathrm{~K}-$ medium and/or deionized water and stored at $4{ }^{\circ} \mathrm{C}$ for more than two days before use. Lytic activity of both supernatant and HILIC fractions were quantified as half maximal effective concentrations $\left(\mathrm{EC}_{50}\right.$, expressed as $\mathrm{EC}_{50}$ and $95 \%$ confidence interval) with a $R$. salina bioassay (Ma et al., 2009).

\subsubsection{Fluorimetric measurements of intracellular $\mathrm{Ca}^{2+}$ changes} PC12 cells were incubated in buffer (in mM: $125 \mathrm{NaCl}, 2.5$ $\mathrm{KCl}, 1 \mathrm{MgCl}_{2}, 2.0 \mathrm{CaCl}_{2}, 1.3 \mathrm{NaH}_{2} \mathrm{PO}_{4}, 30$ glucose, $26 \mathrm{Na}$ HEPES) containing $5 \mu \mathrm{M}$ Fura II acetoxymethylester (SigmaAldrich, Deisenhofen, Germany) for $30 \mathrm{~min}$ at room temperature $\left(22 \pm 2{ }^{\circ} \mathrm{C}\right)$. The incubation buffer was removed from the cultured cells and replaced with $1 \mathrm{~mL}$ buffer. Fluorescence of cells was monitored by an imaging system (Visitron, Puchheim, Germany) and a CCD camera (Coolsnap) mounted on an inverted microscope (Zeiss Axiovert 100, Göttingen, Germany). Single PC12 cells (total: 8-30 cells) were simultaneously measured, and separated using "the region of interest" function of the software Metafluor (Meta Imaging Series, Downingtown, USA). Fluorescence was transmitted through a UV objective (Zeiss NeoFluar 20X, Göttingen, Germany). Data were obtained by division of two images (F340/380) - one at $340 \mathrm{~nm}$ and the other at $380 \mathrm{~nm}$ excitation (Grynkiewicz et al., 1985; Bickmeyer et al., 2004, 2010). Fluorescence ratios were not converted into $\mathrm{Ca}^{2+}$ concentrations. Statistics were performed using Prism from Graphpad and Igor (WaveMetrics, Portland, OR, USA). Values of a 2 min period before compound applications were averaged and compared (Student's t-test) to values of the last 2 min (18-20 min experiment duration).

Experiments on calcium influx from the extracellular buffer were performed with buffer as described above and buffer without calcium but supplemented with 2 mM EGTA (ethylene glycol bis-(2-aminoethyl ether)- $N, N, N^{\prime}, N^{\prime}$-tetraacetic acid). In this experiment, solution changes and compound application were performed by a continuous perfusion system. The Alex2 SPE 80\% methanol fraction, purified from $200 \mathrm{~mL}$ supernatant, was applied at $1 \%$ by volume. In another set of experiments, samples of supernatant as well as HILIC fractions from both Alex2 and Alex5 cultures were used. Samples were pipetted as a total $0.5 \mathrm{~mL}$, including $15 \mu \mathrm{L}$ sample in buffer into Petri dishes containing $1 \mathrm{~mL}$ PC12 cells. Because of the lack of effect after adding the low sample concentration, $100 \mu \mathrm{L}$ were added after several minutes. The changes of intracellular $\mathrm{Ca}^{2+}$ concentration expressed as fluorescence emission ratio were recorded. Mechanical disturbances during application of the compounds may lead to spurious cellular $\mathrm{Ca}^{2+}$ level responses due to mechanosensitive $\mathrm{Ca}^{2+}$ permeable ion-channels in PC12 cells, as in most other cells (Bickmeyer, 2005).

The effect of cadmium application to block calcium ionchannels (Weinsberg et al., 1995) on the potency of Alex2 lytic compounds was determined with $0.5 \mathrm{~mL}$ buffer including $90 \mu \mathrm{L}$ Alex2 HILIC fraction in K-medium, as well as $3 \mu \mathrm{L} \mathrm{CdCl}_{2}$ (from $50 \mathrm{mM}$ stock solution), applied to PC12 cells. The change of fluorescence emission after excitation at 340 and $380 \mathrm{~nm}$ was recorded.

\subsection{Liposome leakage assay}

\subsubsection{Preparation of liposome encapsulation of calcein}

Liposomes were prepared according to a modified method of Pinnaduwage and Bruce (1996). $25 \mathrm{mg}$ lipid 
sample including $100 \%$ phosphatidylcholine (PC, SigmaAldrich, Steinheim, Germany) or PC/cholesterol (70:30) were dissolved in $2 \mathrm{~mL}$ chloroform/methanol (3:1). The organic solvent was removed under $\mathrm{N}_{2}$ for $2 \mathrm{~h}$. The lipid film formed was hydrated by $1 \mathrm{~mL}$ North Sea seawater containing $50 \mathrm{mM}$ of the fluorescent probe calcein (SigmaAldrich, Steinheim, Germany). The mixture was ultrasonicated four times for $5 \mathrm{~min}$ at $35 \mathrm{~min}$ intervals in a sonicator bath (VWR, USC300T, Lutterworth, UK) to initiate encapsulation and formation of liposomes. Liposomes were collected from the supernatant by centrifugation (Eppendorf, 5415R, Hamburg, Germany) at $2500 \times \mathrm{g}$ for $10 \mathrm{~min}$ at room temperature. Liposomes were separated from un-encapsulated calcein by size-exclusion chromatography on a Sephadex G50 (Sigma-Aldrich, Steinheim, Germany) column (ca. $1 \times 20 \mathrm{~cm}$ ), and were applied immediately for lysis determination.

\subsubsection{Calcein release from liposomes induced by Triton X-100} and lytic compounds of $A$. tamarense

Calcein is self-quenching at high concentration in that the fluorescence intensity of calcein is low at high concentration. Triton X-100 induces the release of calcein from liposomes, and fluorescence therefore increases due to dilution of calcein in the medium. The leakage of liposomes was monitored fluorometrically at excitation and emission wavelengths of 490 and $515.4 \mathrm{~nm}$, respectively, with a fluorescence spectrophotometer (Horiba Jobin-Yvon, FluoroLog ${ }^{\circledR}-3$, Unterhaching, Germany).

The initial fluorescence intensities of $2.7 \mathrm{~mL}$ samples including North Sea seawater (blank), Triton X-100 (0.1\%), or R. salina, Alex5 or Alex2 supernatant were measured. Then $0.3 \mathrm{~mL}$ liposome sample was added into each cuvette and the fluorescence intensities of each group were measured for $10 \mathrm{~s}$ at $5 \mathrm{~min}$ intervals until $30 \mathrm{~min}$. Release of calcein was calculated from the following formula

$\%$ leakage $=100\left(F-F_{0 t}\right) /\left(F_{T t}-F_{0 t}\right)$

Where $F$ is the fluorescence after the addition of liposome to the sample, $F_{0 t}$ is the fluorescence at each measuring time point, and $F_{T t}$ is the fluorescence after liposomes were added to $0.1 \%$ Triton $\mathrm{X}-100$ at each measuring time point.

\subsection{Protist sterol composition}

\subsubsection{Cell pellet preparation}

Protist cultures were centrifuged (Eppendorf 5810R, Hamburg, Germany) at $3220 \times \mathrm{g}$ for $10 \mathrm{~min}$ at $15^{\circ} \mathrm{C}$ to acquire cell pellets for direct sterol analysis or plasma membrane isolation. The numbers of cells harvested of whole cell and plasma membrane fraction, respectively, of each strain are as follows: Alex2 $\left(9.8 \times 10^{5}\right.$ and $\left.4.4 \times 10^{6}\right)$, Alex5 $\left(1.1 \times 10^{6}\right.$ and $\left.3.3 \times 10^{6}\right)$, D. salina $\left(3.3 \times 10^{7}\right.$ and $\left.2.1 \times 10^{8}\right)$, H. akashiwo $\left(9.8 \times 10^{6}\right.$ and $\left.4.9 \times 10^{7}\right)$, O. marina $\left(1.4 \times 10^{6}\right.$ and $\left.1.0 \times 10^{7}\right)$, G. dominans $\left(4.4 \times 10^{5}\right.$ and $1.7 \times 10^{6}$ ). For $R$. salina, the cell number was $4.1 \times 10^{8}$ for plasma membrane. The cell pellets for whole cell sterol composition analysis were stored at $-20{ }^{\circ} \mathrm{C}$ before use, whereas those for plasma membrane preparation were further processed immediately after centrifugation.

\subsubsection{Plasma membrane preparation and characterization}

2.4.2.1. Plasma membrane enrichment. Cell pellets were resuspended in $5 \mathrm{~mL}$ disruption buffer composed of $400 \mathrm{mM}$ mannitol, $2 \mathrm{mM}$ EDTA, $1 \mathrm{mM} \mathrm{MgCl}_{2}, 100 \mathrm{mM}$ $\mathrm{Na}_{3} \mathrm{PO}_{4}$, pH 7.4 (Peeler et al., 1989). For each sample, the cell suspension was disrupted by a French Press at 16,000 psi. Each homogenized sample was centrifuged at $2960 \times \mathrm{g}$ for $5 \mathrm{~min}$ at $4{ }^{\circ} \mathrm{C}$. The supernatant was transferred to a $15 \mathrm{~mL}$ Sarstedt tube and further purified by two-phase partitioning. Both dextran T500 (13.4\%, w/w) and polyethylene glycol (PEG) $3350(26.8 \%, w / w)$ solution stocks were added to reach a final concentration of $6.7 \%(\mathrm{w} / \mathrm{w})$, respectively. The mixture was inverted 40 times, and was immediately centrifuged at $660 \times \mathrm{g}$ for $10 \mathrm{~min}$ at $4{ }^{\circ} \mathrm{C}$. The upper PEG phase was ultracentrifuged at $121,000 \times g$ (Beckmann Coulter, Optimal $^{\mathrm{TM}}$ LE-80K, Krefeld, Germany) for $1 \mathrm{~h}$ at $4{ }^{\circ} \mathrm{C}$, and the supernatants were carefully removed by pipette. The residue was re-suspended with $2 \mathrm{~mL}$ disruption buffer, and again ultracentrifuged as above to pellet the membrane microsomes. The membrane samples were stored at $-20{ }^{\circ} \mathrm{C}$ for sterol compositional analysis.

2.4.2.2. Vanadate-sensitive ATPase. Determination of vanadate-sensitive ATPase activity was performed with reference to the method of Gallagher and Leonard (1982). For analysis of plasma membrane purity, an Alex2 cell pellet (ca. $5.5 \times 10^{6}$ cells) was used to prepare cell membrane fractions as described above. After the first ultracentrifugation, the residue was washed with $2 \mathrm{~mL}$ $10 \mathrm{mM}$ Tris- $\mathrm{HCl}$ buffer, $\mathrm{pH} 7.5$, including $250 \mathrm{mM}$ sucrose, and again ultracentrifuged. The pellet was re-suspended in $600 \mu \mathrm{L}$ Tris- $\mathrm{HCl}$ buffer, and stored at $-70^{\circ} \mathrm{C}$. One fifth of the dextran T500 fraction was diluted 10 -fold with Tris- $\mathrm{HCl}$ buffer, and the following steps were the same as for the PEG fraction.

Total protein was quantified by the bicinchoninic acid (BCA) assay (Smith et al., 1985), performed as described in the BCA assay kit (Pierce, Thermo Fisher Scientific Bonn, Germany). Briefly, $50 \mu \mathrm{L}$ sample from membrane fractions or albumin standard solutions were mixed with $1 \mathrm{~mL}$ working reagent containing 50 parts solution $\mathrm{A}, 1$ part solution B, and $0.01 \%$ Triton X-100 (w/w). The mixtures were incubated in a water bath for $30 \mathrm{~min}$ at $60{ }^{\circ} \mathrm{C}$, then cooled to room temperature and read spectrophometrically at $562 \mathrm{~nm}$. The protein content of membrane samples was calculated according to the standard curve.

ATPase activity was determined according to Briskin et al. (1987). Assays were carried out in a $1 \mathrm{~mL}$ reaction volume with $20 \mu \mathrm{L}$ membrane fraction and $980 \mu \mathrm{L}$ reaction buffer containing $5 \mathrm{mM} \mathrm{MgSO}_{4}, 5 \mathrm{mM}$ ATP $\mathrm{Na}_{2}, 30 \mathrm{mM}$ TrisMES (pH 6.5), $50 \mathrm{mM} \mathrm{KCl}$ (when present), and $50 \mu \mathrm{M}$ $\mathrm{Na}_{3} \mathrm{VO}_{4}$ (when present). The reaction was performed at $38^{\circ} \mathrm{C}$ for $1 \mathrm{~h}$, and then terminated by adding $2.6 \mathrm{~mL}$ color development solution consisting of six parts $0.42 \%(\mathrm{w} / \mathrm{v})$ ammonium molybdate in $1 \mathrm{~N} \mathrm{H}_{2} \mathrm{SO}_{4}$ and $10 \%(\mathrm{w} / \mathrm{v})$ ascorbic acid. The optical density was determined spectrophotometrically at $700 \mathrm{~nm}$ after incubation at room temperature for $20 \mathrm{~min}$. 


\subsection{Sterol compositional analysis}

Cell pellet or plasma membrane fractions were lyophilized (Freeze Dryer, Osterode am Harz, Germany) overnight. Lipids were extracted by mixing $10 \mathrm{~mL} n$-hexane per $2 \mathrm{mg}$ lyophilizate and subsequent ultrasonication for $10 \mathrm{~min}$, and then were left at room temperature for $3 \mathrm{~h}$ for complete solubilization of lipids. After centrifugation (Hettich, EBA $8 \mathrm{~S}$, Tuttlingen, Germany) at $855 \times g$, the supernatant was removed and evaporated under $\mathrm{N}_{2}$. Sterols were derivatized with N-methyl-n-trifluoroacetamide (MachereyNagel, Düren, Germany). For sample amounts up to $5 \mathrm{mg}$, $50 \mu \mathrm{L}$ of derivatization reagent was added to the dry sample in a micro-sampling vial and stored for $2 \mathrm{~h}$ at $70{ }^{\circ} \mathrm{C}$ in a thermoblock.

The silylated sterols were analyzed by gas chromatography coupled to mass spectrometry (GC-MS). Gas chromatography was performed on a 3800 GC System (Varian, Palo Alto, CA, USA). Separation was achieved on a lowbleeding CPSil 8CB MS fused-silica capillary column (30 $\mathrm{m} \times 0.25 \mathrm{~mm}$ i.d. $\times 0.25 \mu \mathrm{m}$ film thickness) (Chrompack, Middelburg, Netherlands). Detection was carried out by an MS/MS 2000 Ion-Trap Detector (Varian, Palo Alto, CA, USA) with GC-MS operation control and data processing by the Varian Saturn MS Workstation 6.9.2 software. The sample volume in the direct injection mode was $1 \mu \mathrm{L}$. Gas chromatographic analysis was started at $200{ }^{\circ} \mathrm{C}$ and held for $1 \mathrm{~min}$ and then increased to $320^{\circ} \mathrm{C}$ at a heating rate of $40{ }^{\circ} \mathrm{C}$ per min, remaining constant for $36 \mathrm{~min}$. The total run time was $40 \mathrm{~min}$.

The sterol standards brassicasterol, desmosterol, ergosterol, cholesterol, stigmasterol, and stigmastanol were purchased from Sigma-Aldrich (Taufkirchen, Germany) and beta-sitosterol from BIOTREND Chemikalien $\mathrm{GmbH}$ (Cologne, Germany). Standard sterol solutions were run as reference and samples were quantified by external calibration. The amounts of campesterol, corbisterol and dinosterol were calculated as cholesterol equivalents. Only sterol peaks above the limit of quantitation $(s / n$ ratio $>10)$ were reported.

\subsection{Lipid incubation bioassay}

Three common and representative sterols, namely cholesterol, ergosterol and brassicasterol, are major sterols of A. tamarense and O. marina, D. salina, and $R$. salina, respectively, and therefore were selected for competitive binding assay. Phosphatidylcholine (PC) as a basic membrane component was also applied for the assay. Methanolic standard stock solutions of cholesterol, ergosterol, brassicasterol (Sigma-Aldrich, Taufkirchen, Germany) and $P C$ at different concentrations $\left(1 \times 10^{6}, 10^{5}\right.$, $10^{4}, 10^{3}$, and $\left.10^{2} \mathrm{nmol} \mathrm{L}^{-1}\right)$ were prepared for a supernatant incubation assay. For each concentration of each sterol, a five-point $4 \mathrm{~mL}$ bioassay (Ma et al., 2009) was performed in triplicate, containing $0.04 \mathrm{~mL}$ standard sterol stock solution; and 500, 250, 100, 50, $25 \mu \mathrm{L}$ Alex2 culture supernatant. The PC binding assay was performed in an identical fashion but with a different batch of supernatant. An aliquot of $0.1 \mathrm{~mL} R$. salina culture (final bioassay concentration: $10 \times 10^{3} \mathrm{~mL}^{-1}$ ), and $0.2 \mu \mathrm{m}$ filtered seawater made up the remaining volume. Supernatant was applied alone as a positive control of lytic activity. After $3 \mathrm{~h}$ incubation, the number of intact $R$. salina cells in each vial was quantified. The results were expressed as percentage relative to controls (intact $R$. salina cells in K-medium).

\section{Results}

\subsection{Putative main target site of lytic compounds}

In the lytic assay with $R$. salina, independent application of Alex2 supernatant and the HILIC fraction yielded $\mathrm{EC}_{50}$ values of $0.68 \%(0.61-0.77 \%)$ and $0.83 \%(0.68-1.02 \%)$, respectively. No lysis of $R$. salina cells was observed for any undiluted Alex 5 fractions.

The SPE fractions of Alex2 increased intracellular $\mathrm{Ca}^{2+}$ levels significantly only in the presence of extracellular $\mathrm{Ca}^{2+}$, whereas no alteration of intracellular $\mathrm{Ca}^{2+}$ concentration was detected when extracellular $\mathrm{Ca}^{2+}$ was absent (Fig. 1, right panel). This indicates that rather than directly affecting the intracellular $\mathrm{Ca}^{2+}$ pool, lytic compounds target PC12 cell plasma membranes, and either act directly on $\mathrm{Ca}^{2+}$ channels or damage membrane integrity.

Application of either Alex 5 supernatant or HILIC fraction at high concentration (5.75\%) did not alter intracellular $\mathrm{Ca}^{2+}$ concentration of PC12 cells (Fig. $1 \mathrm{~A}$ and $\mathrm{B}$ ). In contrast to treatments with Alex5 fractions, the intracellular $\mathrm{Ca}^{2+}$ concentration was increased after addition of Alex2 fractions. Although at a low concentration (1\%) only weak or no alterations were observed in any group (Fig. 1D and E, left box), at high concentration (5.75\%), both Alex2 supernatant and HILIC fraction in K-medium caused a significant increase in intracellular $\mathrm{Ca}^{2+}$ concentration (Fig. 1D and $\mathrm{E}$, right box) within a short time (ca. $10 \mathrm{~min}$ ). However, an Alex2 HILIC fraction taken up in deionized water, and subsequently applied at the same concentration as in $\mathrm{K}$ medium, showed no effect on intracellular $\mathrm{Ca}^{2+}$ concentration (Fig. 1C). When $\mathrm{CdCl}_{2}$, a blocker of $\mathrm{Ca}^{2+}$ channels, was present, the increase of intracellular $\mathrm{Ca}^{2+}$ concentration caused by the HILIC fraction of Alex2 was not inhibited (Fig. 1F), as the increase of intracellular $\mathrm{Ca}^{2+}$ was significant.

\subsection{Liposome leakage assay}

Both Alex2 and Alex5 supernatant (90\% volume), and to a lesser extent supernatant from the cryptophyte Rhodomonas, were capable of lysing PC liposomes. The fact that the time course of calcein release was almost identical between the supernatant of the lytic (Alex2) versus the non-lytic strain (Alex5) (Fig. 2A), with lytic activity as defined with reference to effects on Rhodomonas cells, suggested that this effect against PC liposomes represents non-specific perhaps detergent-like activity.

In contrast, although both Alex2 and Alex5 supernatant (90\% volume) also lysed PC/cholesterol liposomes, Alex2 supernatant caused more calcein release than Alex5 supernatant (Fig. 2B), and the time course of fluorescence increase was different. With Alex2 supernatant, fluorescence yield almost reached $100 \%$ of the Triton $\mathrm{X}$ maximum after $30 \mathrm{~min}$ incubation. This indicated that the lytic 


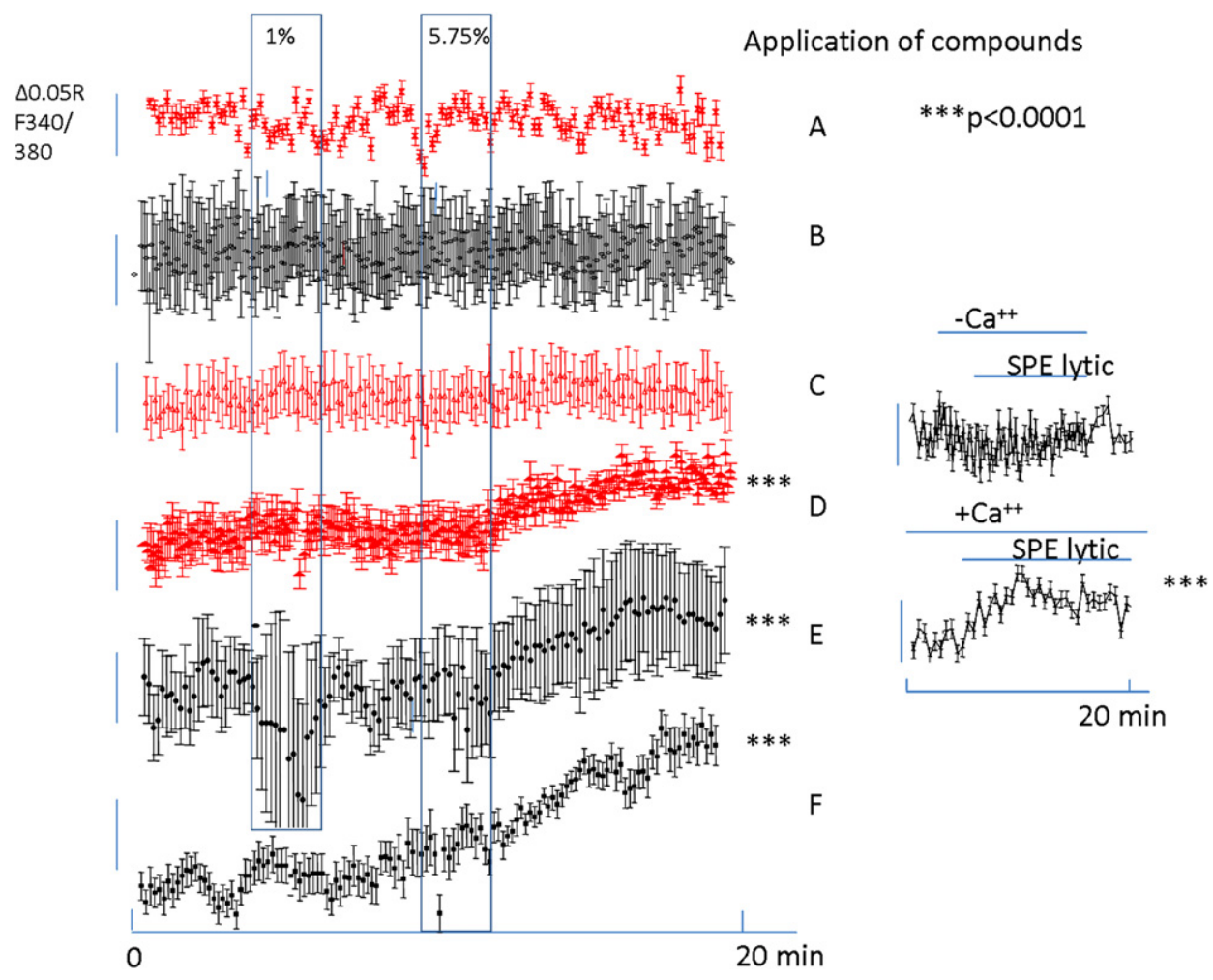

Fig. 1. Intracellular fluorescence of cells separated using the "region of interest" function of the software (Metafluor, Meta Imaging Series) obtained through a UV objective (Zeiss NeoFluar 20×). Data represent the fluorescence ratio of two images (F340/380), at $340 \mathrm{~nm}$ and $380 \mathrm{~nm}$ excitation. Increases in F340/380 are equivalent to rises in intracellular calcium levels. A ratio increase of 0.05 (scale bar) represents an elevation of free Ca ${ }^{2+}$ of roughly 50 nM. The long boxes indicate the time window during which samples at final concentrations of $1 \%$ and $5.75 \%$, respectively, were added. A. Alex 5 supernatant; B. Alex 5 HILIC fraction; C. Alex 2 HILIC fraction in water; D. Alex2 HILIC fraction in K-medium; E. Alex2 supernatant; F. $6 \%$ Alex2 HILIC fraction with $100 \mu \mathrm{M}$ CdCl 2 . $8-15$ cells were measured simultaneously (error bars: SEM). $P<0.0001=* * *$. The right part of the figure shows experiments demonstrating the compound-induced calcium influx only in the presence of extracellular calcium. Horizontal bars indicate time course of treatments.

compounds interacted with cholesterol within liposome membranes, thereby enhancing lysis and calcein release.

\subsection{Control for plasma membrane isolation}

The results of the ATPase activity with or without potassium or vanadate in fractions of the two phases are shown in Table 1. The presence of potassium did not significantly increase ATPase activity in either fraction. Vanadate significantly inhibited ATPase activity (Student's $t$-test, $p<0.05$ ) in the PEG phase, whereas no significant inhibition of ATPase activity (Student's $t$-test, $p>0.05$ ) was detected in the dextran phase. This indicated that plasma membrane-related vanadate-sensitive ATPase was preferentially partitioned into the PEG phase, and thus the isolated PEG fraction was enriched in plasma membrane.

\subsection{Sterol composition}

The sterol composition of whole cells (Table 2) of both Alexandrium strains Alex2 and Alex5 comprised mainly cholesterol $(>50 \%)$ and the 4-methyl sterol dinosterol ( $>25 \%$ ). The cryptophyte $R$. salina contained $100 \%$ brassicasterol, whereas the major sterols of the chlorophyte $D$. salina and the raphidophyte $H$. akashiwo were ergosterol (49\%) and corbisterol (51\%), and $\beta$-sitosterol (98\%), respectively. The heterotrophic dinoflagellates 0 . marina and $G$. dominans fed on $D$. salina contained cholesterol and stigmastanol, respectively.

In most cases, plasma membrane fractions from both $A$. tamarense strains and five target protists enriched by PEG/ dextran partitioning yielded different sterol compositions (Table 3) compared to those of whole cells. No compositional differences between whole cell extracts and plasma membrane fractions were observed only for R. salina $(100 \%$ brassicasterol) and $H$. akashiwo (98\% $\beta$-sitosterol). In contrast, the sterol ratios of the fractions of the other species differed, often dramatically. For example, plasma membrane fractions of Alex 2 and Alex5 contained mainly cholesterol (>88\%), but less than $10 \%$ dinosterol (Table 3 ), whereas the whole cell extract contained $26 \%$ and $42 \%$ dinosterol for Alex2 and Alex5, respectively (Table 2). Even more pronounced differences can be seen for the species $D$. salina, O. marina, and G. dominans. For example, plasma membrane fractions of these three species are enriched in desmosterol (Table 3), but this sterol component falls below the limit of quantitation in whole cell extracts (Table 2 ). In any case, none of the five target species, which are 


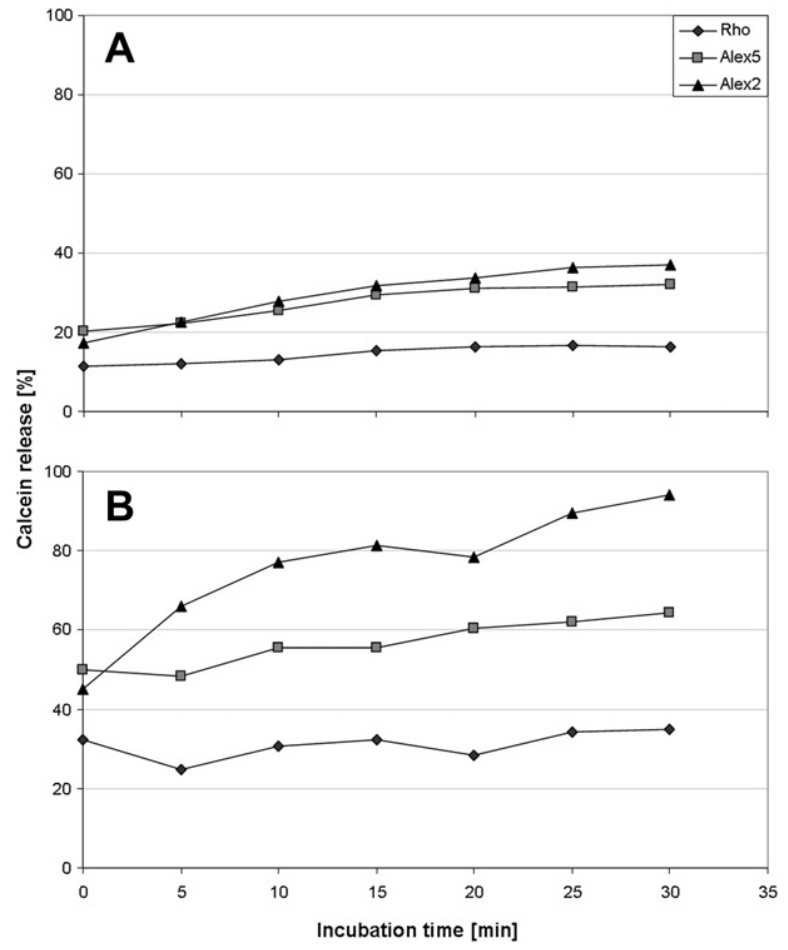

Fig. 2. Percentage of calcein released from liposomes induced by $R$. salina or A. tamarense supernatant (relative to maximum release by Triton X-100). A. PC liposome; B. PC/cholesterol (70/30) liposome. Alex2 = A. tamarense lytic strain; Alex $5=A$. tamarense non-lytic strain; Rho $=R$. salina .

lysed by Alex2 exudates, contained any trace of the 4methyl sterol dinosterol.

\subsection{Lipid incubation bioassay}

Assays with three representative sterols, cholesterol, ergosterol and brassicasterol, and the basic membrane component PC, showed an increase in the percentage of intact $R$. salina cells when these sterols were incubated at high concentration together with supernatant from Alex2 (Fig. 3). Total lytic activity of Alex2 supernatant, which caused $100 \%$ lysis of $R$. salina in the lipid-free control treatment, was completely inhibited by all four lipids at the highest concentration $\left(1 \times 10^{4} \mathrm{nmol} \mathrm{L}^{-1}\right.$, Fig. 3A-D). Nevertheless, at the next lower sterol concentration $1 \times 10^{3} \mathrm{nmol} \mathrm{L}^{-1}$ only cholesterol yielded $100 \%$ intact $R$. salina cells (Fig. 3A), suggesting higher affinity of lytic compounds for cholesterol than for the other sterols. Comparison of ergosterol and brassicasterol at a concentration of $100 \mathrm{nmol} \mathrm{L}^{-1}$ simultaneously

Table 1

Plasma membrane enzyme marker activities ( $\mu \mathrm{mol} \mathrm{Pi} \mathrm{mg}$ protein ${ }^{-1} \mathrm{~min}^{-1}$ ) in two membrane fractions in the presence or absence of co-factor/inhibitor (results expressed as mean \pm s.d., $n=3$ ).

\begin{tabular}{lll}
\hline ATPase & PEG phase (plasma membrane) & Dextran phase \\
\hline$-\mathrm{K}^{+}$ & $0.19 \pm 0.04$ & $0.38 \pm 0.02$ \\
$+\mathrm{K}^{+}$ & $0.21 \pm 0.05$ & $0.40 \pm 0.06$ \\
$+\mathrm{K}^{+},+$vanadate & $0.05 \pm 0.01$ & $0.28 \pm 0.06$ \\
\hline
\end{tabular}

Table 2

Sterol composition (\%) of whole cells of A. tamarense and target protistan species.

\begin{tabular}{|c|c|c|c|c|c|c|c|}
\hline Sterol & Alex2 & Alex5 & $\begin{array}{l}R . \\
\text { salina }\end{array}$ & $\begin{array}{l}D . \\
\text { salina }\end{array}$ & $\begin{array}{l}\text { H. } \\
\text { akashiwo }\end{array}$ & $\begin{array}{l}O . \\
\text { marina }\end{array}$ & $\begin{array}{l}\text { G. } \\
\text { dominans }\end{array}$ \\
\hline Cholesterol & 73.0 & 55.6 & 0.0 & 0.0 & 0.0 & 68.4 & 0.0 \\
\hline Ergosterol & 0.0 & 0.0 & 0.0 & 48.8 & 0.0 & 0.0 & 0.0 \\
\hline Brassicasterol & 0.0 & 0.0 & $100.0^{\mathrm{a}}$ & 0.0 & 0.0 & 0.0 & 0.0 \\
\hline Dinosterol & 26.0 & 41.7 & 0.0 & 0.0 & 0.0 & 0.0 & 0.0 \\
\hline Stigmasterol & 0.0 & 0.0 & 0.0 & 0.0 & 0.2 & 7.3 & 0.0 \\
\hline Desmosterol & 0.0 & 0.0 & 0.0 & 0.0 & 0.0 & 0.0 & 0.0 \\
\hline$\beta$-Sitosterol & 1.0 & 2.6 & 0.0 & 0.0 & 97.9 & 0.0 & 0.0 \\
\hline Stigmastanol & 0.0 & 0.1 & 0.0 & 0.0 & 0.0 & 0.0 & 100.0 \\
\hline Campesterol & 0.0 & 0.0 & 0.0 & 0.0 & 1.9 & 24.3 & 0.0 \\
\hline Corbisterol & 0.0 & 0.0 & 0.0 & 51.2 & 0.0 & 0.0 & 0.0 \\
\hline
\end{tabular}

${ }^{a}$ Data based on preliminary result acquired from a cell pellet for which cell number was not recorded.

applied with Alex2 supernatant $(250 \mu \mathrm{L})$ showed higher affinity of lytic compounds for ergosterol than brassicasterol. At the two lowest concentrations ( 1 and $10 \mathrm{nmol} \mathrm{L}^{-1}$ ), all three sterols reduced lytic activity in $100 \mu \mathrm{L}$ sample volume, but differences among the effect of these sterols were not distinguishable. Furthermore, the two lowest concentrations of the same sterol reduced the lytic activity by almost the same extent. In summary, the lytic compounds showed binding effects to free sterols. The lytic compounds exhibited different affinities to the three tested sterols, with the highest binding to cholesterol followed by ergosterol and brassicasterol, but lytic activity was also reduced dose dependently by the presence of PC.

\section{Discussion}

The ecological role of allelopathy among microalgae is believed to relate to bloom formation and succession of certain species via competitive interactions (Keating, 1977; Legrand et al., 2003; Kubanek et al., 2005). Among microalgae, allelopathy is reported to mainly influence the survival of target species by inhibition of growth, photosynthetic pathways, immobilization, or even causing death of target microalgae (Legrand et al., 2003; Granéli and Hansen, 2006; Tillmann et al., 2008b). Exposure of sensitive target organisms, e.g. the cryptophyte $R$. salina, to allelochemicals from the dinoflagellate $A$. tamarense, yields cell lysis in a relatively short time of several minutes. The

\section{Table 3}

Sterol composition (\%) of plasma membrane-enriched fractions from A. tamarense and target protistan species.

\begin{tabular}{|c|c|c|c|c|c|c|c|}
\hline Sterol & Alex2 & Alex5 & $\begin{array}{l}R \text {. } \\
\text { salina }\end{array}$ & $\begin{array}{l}\text { D. } \\
\text { salina }\end{array}$ & $\begin{array}{l}\text { H. } \\
\text { akashiwo }\end{array}$ & $\begin{array}{l}\text { O. } \\
\text { marina }\end{array}$ & $\begin{array}{l}\text { G. } \\
\text { dominans }\end{array}$ \\
\hline Cholesterol & 93.0 & 88.1 & 0.0 & 8.0 & 0.0 & 9.9 & 11.5 \\
\hline Ergosterol & 0.0 & 0.0 & 0.0 & 0.0 & 0.0 & 0.0 & 0.0 \\
\hline Brassicasterol & 0.0 & 0.0 & 100.0 & 0.0 & 0.0 & 0.0 & 0.0 \\
\hline Dinosterol & 2.9 & 8.1 & 0.0 & 0.0 & 0.0 & 0.0 & 0.0 \\
\hline Stigmasterol & 0.0 & 0.0 & 0.0 & 0.0 & 0.3 & 6.2 & 18.5 \\
\hline Desmosterol & 4.1 & 3.8 & 0.0 & 44.7 & 0.0 & 33.8 & 38.8 \\
\hline$\beta$-Sitosterol & 0.0 & 0.0 & 0.0 & 32.3 & 97.9 & 50.1 & 0.0 \\
\hline Stigmastanol & 0.0 & 0.0 & 0.0 & 15.0 & 0.0 & 0.0 & 31.2 \\
\hline Campesterol & 0.0 & 0.0 & 0.0 & 0.0 & 1.8 & 0.0 & 0.0 \\
\hline Corbisterol & 0.0 & 0.0 & 0.0 & 0.0 & 0.0 & 0.0 & 0.0 \\
\hline
\end{tabular}




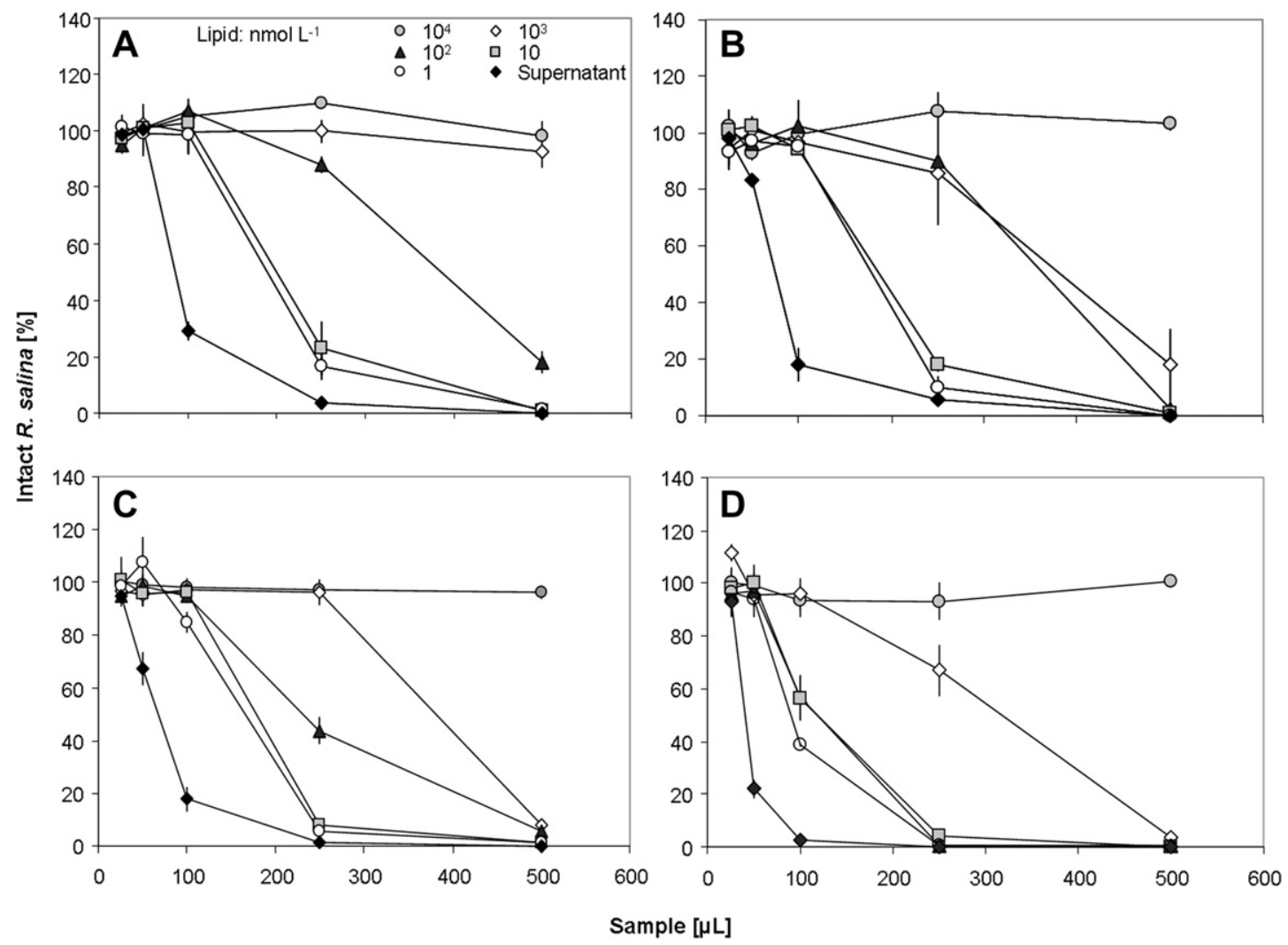

Fig. 3. Percentage (compared to control) of intact $R$. salina cells exposed to five volumes of Alex2 supernatant together with four different lipids at five concentrations. A. Cholesterol. B. Ergosterol. C. Brassicasterol. D. Phosphatidylcholine (PC). Results expressed as triplicate mean \pm SD.

intuitive hypothesis that such rapid cell lysis of target microalgae is caused by direct membrane disruption, as opposed to the induction of other catabolic cascades within the cell, however, remained to be proven.

The choice of a mammalian cell model, PC 12 cells, rather than more ecologically relevant putative target species, to investigate the mode of action of the lytic compounds produced by $A$. tamarense was based upon pragmatic considerations. Membrane systems of mammalian cells have been much more intensively studied, and in any case all eukaryotic cell membranes share basic structural similarities.

Research on the mode of action of cytotoxicity, including hemolytic effects, of known phycotoxins on a variety of cell types has demonstrated two main mechanisms of cell lysis - some toxins induce apoptosis, whereas others directly disrupt plasma membranes. For example, microcystins produced by some strains of the cyanobacteria Microcystis, Anabaena, and Oscillatoria (Sivonen et al., 1990; Fujiki and Suganuma, 1993; Bell and Codd, 1996; Fawell et al., 1999; Chorus et al., 2000), and diarrhetic shellfish poisoning (DSP) toxins, such as okadaic acid (OA) and dinophysistoxin-1, produced by dinoflagellates belonging to the genera Dinophysis and Prorocentrum (Yasumoto et al., $1979,1984)$ belong to the first type. Although these toxin groups are structurally and biosynthetically unrelated, they share the capacity to act as potent protein phosphatase inhibitors in mammalian cells, and also exert allelopathic effects on certain macroalgae (Pflugmacher, 2002) and microalgae (Windust et al., 1996, 1997). With respect to cytotoxicity to mammalian cell lines, these toxins were reported to induce apoptosis of target cells, e.g. microcystins bind and inhibit catalytic subunits of the wellconserved intracellular serine/threonine protein phosphatase (PP) 1 and 2A (Holmes and Boland, 1993; Goldberg et al., 1995), and consequently cause a series of chain reactions, and finally apoptosis of target cells. By a similar mechanism, OA and its analogs also induce apoptosis of target cells (Tergau et al., 1997; Rossini, 2000; Klumpp and Krieglstein, 2002). Here it is important to note that the allelochemical lytic activity of Alexandrium is unrelated to phosphatase inhibition activity, at least as mediated by these toxins (they are absent). Furthermore, the lytic activity it also apparently unrelated to the presence or content of tetrahydropurine neurotoxins (saxitoxin and analogs) with $\mathrm{Na}$-channel blocking activity often found within this genus (Tillmann and John, 2002).

In virtually all eukaryotic cell types, $\mathrm{Ca}^{2+}$ is an important intracellular messenger, inducing death signals if delivered in unsuitable circumstances (Berridge et al., 2000; Hajnoczky et al., 2000). Both $\mathrm{Ca}^{2+}$ influx through plasma membrane channels and release from endoplasmic reticulum can stimulate cell apoptosis. In our experiments, when the PC 12 cells were exposed to lytic compounds 
from Alexandrium, the intracellular $\mathrm{Ca}^{2+}$ concentration increased and this enhancement was proven to originate from the extracellular medium, as no alteration of intracellular $\mathrm{Ca}^{2+}$ was observed when extracellular $\mathrm{Ca}^{2+}$ was absent. We interpret this to indicate that the lytic compounds do not interact with intracellular $\mathrm{Ca}^{2+}$ stores, but rather act directly on the plasma membrane, either by interacting with $\mathrm{Ca}^{2+}$ channels or by forming pores or causing disruption of the plasma membrane. By comparison, the large polyether maitotoxin (MTX) produced by the dinoflagellate Gambierdiscus toxicus (Yokoyama et al., 1988) elicits $\mathrm{Ca}^{2+}$ influx in virtually all cells and tissues by activation of ion-channels (Gusovsky et al., 1989), and subsequently causing a intracellular cascade of events.

The use of the $\mathrm{Ca}^{2+}$ channel blocker $\mathrm{CdCl}_{2}$ assisted in the discrimination of ion channel activation, as it has been described for MTX, from an alternative mode of action for the lytic compounds from Alexandrium. The $\mathrm{CdCl}_{2}$ inhibition assay, in which $\mathrm{Ca}^{2+}$ channels in the plasma membrane were blocked, showed that intracellular $\mathrm{Ca}^{2+}$ concentrations continued to increase. This effect indicates that the lytic compounds directly disrupt the plasma membrane rather than inducing apoptosis by activation of ion-channels. We interpret the increase in intracellular $\mathrm{Ca}^{2+}$ to be the result of enhanced influx of $\mathrm{Ca}^{2+}$ through damaged sites in the membrane.

Significantly, there was no influx of $\mathrm{Ca}^{2+}$ into PC12 cells when the lytic Alex2 HILIC fraction had previously been taken up in deionized water. This is consistent with our previous observation that the lytic compounds had less lytic effect on $R$. salina cells when re-suspended in deionized water than in seawater (Ma et al., 2009). We speculated that the bioactivity against the cell membrane targets of the lytic compounds is dependent upon a critical secondary or tertiary conformational structure, which is maintained in saline environments, such as in natural seawater including with nutrient enrichments, e.g. Kculture medium, but is lost in fractions in organic solvents or deionized water.

Phosphatidylcholine is a basic component of bilayer biomembranes. The lytic compounds showed affinity to PC, indicating that the lysis of target membrane could be caused by interaction of lytic compounds with membrane PC. However, the result of the liposome assay, for which the presence of the lytic compounds in the supernatant did not enhance or alter the time course of PC liposome lysis, suggests that the mechanism of membrane lysis of sensitive protist cells by lytic compounds of Alexandrium is not a non-specific detergent-like activity. The different calcein release potencies and time course of fluorescence yield of $\mathrm{PC} /$ cholesterol liposomes exposed to Alex2 versus Alex5 supernatant appear to be related to the presence of cholesterol in liposome membrane. We hypothesize that specific activity of the lytic compounds is a function of cholesterol in the membrane, with cholesterol likely serving as a molecular target of the lytic compounds.

As putative allelochemical(s), it is therefore intriguing that the lytic compounds of Alexandrium are capable of disrupting the cell plasma membrane of target microalgal cells. Similar membrane-disruptive effects of dinoflagellate secondary metabolites have been reported for species of the genus Amphidinium (Houdai et al., 2004) and Karlodinium (Deeds and Place, 2006). The amphipathic hemolytic toxins, e.g. amphidinols with hairpin structures, are believed to interact with sterols located in the membrane, and to increase the membrane permeability by forming pores in the membrane (Houdai et al., 2005). Karlotoxins (KmTxs) are another group of toxic dinoflagellate metabolites, with structures similar to amphidinols (Van Wagoner et al., 2008). KmTx-2 exhibited different affinities to gymnodinosterol, a 4-methyl sterol from Karlodinium veneficum, cholesterol (found in erythrocytes as well as 0 . marina), and ergosterol, a fungal sterol (Deeds and Place, 2006). The latter authors concluded that Karlodinium protects itself from being lysed by the karlotoxins it produces by the presence of 4-methylated gymnodinosterol in its plasma membrane, which thus remained intact. In other words, karlotoxins are capable of lysing other cells, such as erythrocytes, as well as fungi and protists, by specifically binding to non-4-methyl sterols, such as cholesterol or ergosterol on target membranes. Such sterol-specific bioactivity is similar to the action of some antibiotics, e.g. the polyene amphotericin B, which specially bind to ergosterol but not to cholesterol on membranes, thus can be used on human cells whose membranes contain cholesterol.

Similarly, the lytic compounds of Alexandrium could conceivably behave in a sterol-binding selective manner. The fact that $A$. tamarense lytic compounds bind to non-4methyl sterols and that this species contains the 4-methyl sterol dinosterol is consistent with the karlotoxin model system, whereby dinosterol could be a candidate for a selfprotective agent against the lytic compounds produced by A. tamarense. Unfortunately we were not able to test the specific binding affinity of lytic compounds from Alexandrium to dinosterol due to unavailability of this purified compound. In any case, the sterol profile of $\mathrm{K}$. micrum consists only of 4-methyl sterols (Leblond and Chapman, 2002), whereas A. tamarense contains both cholesterol and the 4-methylated dinosterol (26 and $41.7 \%$ of total sterol content for two different strains tested, respectively). The presence of the former sterol in A. tamarense does not support this sterol-specific hypothesis, because cholesterol showed a high binding affinity to $A$. tamarense lytic compounds and thus would counteract the protective role of dinosterol.

Sterols are present not only in the plasma membrane but also in other organelles and membranes inside the cell. Nevertheless, it is apparent that only sterols present in the plasma membrane will directly encounter lytic compounds, and therefore the sterol composition of the plasma membrane is critical for understanding the mode of action and cellular target of lytic compounds, and whether or not sterol-binding is involved. Unexpectedly, in the enriched plasma membrane fractions of both Alexandrium strains, the cholesterol component was an even higher percentage ( $>88 \%$ ) of total sterols, than in the whole cell fraction. Among the target species, $R$. salina contained $100 \%$ brassicasterol, and other species contained various sterols in their plasma membranes, but none possessed dinosterol (Table 3). This practically rules out the self-protective function of dinosterol for Alexandrium against its lytic compounds because if sterols are the binding target of 
these lytic compounds Alexandrium cells would also be lysed. Alexandrium cells contain a high percentage of cholesterol in the plasma membrane, and free cholesterol has the highest affinity for lytic compounds.

If sterols really are the molecular targets of lytic compounds, there are two possible explanations for the apparent contradictory results. One is that the sterol composition listed (Table 3 ) does not accurately represent that of the outer membrane surface of $A$. tamarense. The outer layer of thecate dinoflagellates is complex and difficult to define because dinoflagellates possess an amphiesma consisting of multiple layers, including the outermost membrane, amphiesmal vesicles, which for thecate dinoflagellates contain cellulose plates, and the innermost membrane layer in contact with the cytoplasm (Morrill, 1984). In A. tamarense, if the sterol composition of the outermost membrane layers is inconsistent with that of the basal membrane ("plasmalemma"), then the possible contribution of 4-methyl sterol to self-protective mechanisms cannot be excluded. To completely exclude sterols as the active target of lytic compounds, the actual location of sterols must be determined.

Other possibilities are that A. tamarense cells produce protective molecules which shield cholesterol from its lytic compounds or that prevent the lytic compounds from reaching critical intracellular targets. Similar protective modes were found in some prokaryotic organisms. For example, lipopolysaccharides that determine the serotype of Pseudomonas aeruginosa strains may prevent access of Rpyocins, the bacteriocins produced by $P$. aeruginosa, to their receptor sites on the producers (Köhler et al., 2010). Some nitrogen-fixing cyanobacteria, e.g. Nostoc spp., also produce antibiotic substances like bacteriocin against other cyanobacteria, and simultaneously produce a masking protein that inhibits bacteriocin, thereby rendering the producing strain immune to the effects of the bacteriocin (Flores and Wolk, 1986).

Components other than sterols in the plasma membrane may also be the targets of lytic compounds. For example, maitotoxin does not elicit $\mathrm{Ca}^{2+}$ influx into artificial phospholipid vesicles (Takahashi et al., 1982; Murata et al., 1992), but does induce $\mathrm{Ca}^{2+}$ influx into erythrocyte ghosts (Konoki et al., 1999), whose membranes are much more complex. The membrane permeabilizing activity of amphidinols (AM2 and AM3) was remarkably enhanced by the presence of sterols (cholesterol) (Morsy et al., 2008a), or transmembrane protein (glycophorin A) (Morsy et al., $2008 \mathrm{~b}$ ) in artificial liposomes composed of saturated lipids. The possibility that other yet unstudied membrane components serve as the target of lytic compounds cannot be excluded. Although cholesterol in PC/cholesterol liposomes appeared to act as a molecular target of lytic compounds from Alexandrium, other membrane components including other sterols were not tested in this assay and therefore cannot be ruled out with respect to their function in binding and membrane susceptibility. Most likely both the total amount and distribution of sterols and transmembrane components determine the particular fluidity and stability of membranes, and then various combinations determine the differential sensitivity of membranes to lytic compounds. The specific sterol composition of the outermost membrane layer and the presence of other protective agents in A. tamarense still need to be resolved.

\section{Conclusion}

Allelochemicals of $A$. tamarense cause lysis of protistan cells, apparently by direct damage to external membranes and loss of cell integrity. The molecular targets of the lytic compounds do not appear to be ion-channels, such as those for $\mathrm{Ca}^{2+}$, but rather other membrane components. Nevertheless, on the basis of liposome membrane assays, the activity of the lytic compounds is not a non-specific detergent-like effect. Lytic compounds possess affinity for free sterols and PC, and the lysis of protistan targets is dosedependently reduced by adding various sterols and PC. Lytic and non-lytic $A$. tamarense cell membranes contain mainly cholesterol, the sterol with highest affinity to lytic compounds. Different sterol composition of the outermost membrane and the "plasma membrane" fraction of Alexandrium enriched in this study may account for the seemingly contradictory results. Although the chemical structures of the lytic compounds from Alexandrium have not been completely defined, they are probably not structurally related to the membrane-disruptive polyene toxins. The superficial similarities in the lytic responses of target cells to polyene toxins and the lytic substances produced by Alexandrium, and the characteristics of the self-protective mechanism, are therefore unlikely to be totally mediated by the same interaction between specific sterols and/or transmembrane proteins of external membranes.

\section{Acknowledgments}

We thank Dieter Janssen (AWI, Bremerhaven, Germany) for performing the GC-MS analysis and subsequent calculations of sterol composition. Funding was provided to the first author (HM) by the Deutscher Akademischer Austausch Dienst through a DAAD-Helmholtz scholarship. Project financing was provided by the PACES research program of the Alfred Wegener Institute as part of the Helmholtz Foundation initiative in Earth and Environment.

\section{Conflict of interest}

The authors declare that there are no conflicts of interest.

\section{References}

Andreoli, T.E., 1974. The structure and function of amphotericin Bcholesterol pores in lipid bilayer membranes. Ann. N. Y. Acad. Sci. 235, 448-468.

Arzul, G., Seguel, M., Guzman, L., Erard-LeDenn, E., 1999. Comparison of allelopathic properties in three toxic Alexandrium species. J. Exp. Mar. Biol. Ecol. 232, 285-295.

Bell, S.G., Codd, G.A., 1996. Detection, analysis and risk assessment of cyanobacterial toxins. In: Hester, R.E., Harrison, R.M. (Eds.), Agricultural Chemicals and the Environment. Royal Society of Chemistry, Cambridge, pp. 109-122.

Berridge, M.J., Lipp, P., Bootman, M.D., 2000. The versatility and universality of calcium signalling. Nat. Rev. Mol. Cell Biol. 1, 11-21.

Bickmeyer, U., 2005. Bromoageliferin and dibromoageliferin, secondary metabolites from the marine sponge Agelas conifera, inhibit voltage- 
operated, but not store-operated calcium entry in PC12 cells. Toxicon 45, 627-632.

Bickmeyer, U., Drechsler, C., Köck, M., Assmann, M., 2004. Brominated pyrrole alkaloids from marine Agelas sponges reduce depolarizationinduced cellular calcium elevation. Toxicon 44, 45-51.

Bickmeyer, U., Grube, A., Klings, K.W., Pawlik, J.R., Köck, M., 2010. Siphonodictyal B1 from a marine sponge increases intracellular calcium levels comparable to the $\mathrm{Ca}^{2+}$-ATPase (SERCA) inhibitor thapsigargin. Mar. Biotechnol. 12, 267-272.

Blanco, J., Campos, M.J., 1988. The effect of water conditioned by a PSPproducing dinoflagellate on the growth of four algal species used as food for invertebrates. Aquaculture 68, 289-298.

Brajtburg, J., Medoff, G., Kobayashi, G.S., Elberg, S., Finegold, C., 1980. Permeabilizing and hemolytic action of large and small polyene antibiotics on human erythrocytes. Antimicrob. Agents Chemother. $18,586-592$.

Briskin, D.P., Leonard, R.T., Hodges, T.K., 1987. Isolation of the plasma membrane: membrane markers and general principles. In: Packer, L., Douce, R. (Eds.), Methods in Enzymology. Academic Press, London, pp. 542-558.

Chorus, I., Falconer, I.R., Salas, H.J., Bartram, J., 2000. Health risks caused by freshwater cyanobacteria in recreational waters. J. Toxicol. Env. Health-Pt B-Crit. Rev. 3, 323-347.

Dahl, E., Lindahl, O., Paasche, E., Throndsen, J., 1989. The Chrysochromulina polylepis bloom in Scandinavian waters during spring 1988. In: Cosper, E.M., Bricelj, V.M., Carpenter, E.J. (Eds.), Novel Phytoplankton Blooms: Causes and Impacts of Recurrent Brown Tides and Other Unusual Blooms. Springer Verlag, Berlin, pp. 383-405.

de Kruijf, B., Demel, R.A., 1974. Polyene antibiotic-sterol interactions in membranes of Acholeplasma laidlawii cells and lecithin liposomes. 3. Molecular structure of the polyene antibiotic-cholesterol complexes. Biochim. Biophys. Acta 339, 57-70.

Deeds, J.R., Place, A.R., 2006. Sterol-specific membrane interactions with the toxins from Karlodinium micrum (Dinophyceae) - a strategy for self-protection? Afr. J. Mar. Sci. 28, 421-425.

Fawell, J.K., Mitchell, R.E., Everett, D.J., Hill, R.E., 1999. The toxicity of cyanobacterial toxins in the mouse: I Microcystin-LR. Hum. Exp. Toxicol. 18, 162-167.

Fistarol, G.O., Legrand, C., Selander, E., Hummert, C., Stolte, W., Granéli, E., 2004. Allelopathy in Alexandrium spp.: effect on a natural plankton community and on algal monocultures. Aquat. Microb. Ecol. 35, 4556.

Flores, E., Wolk, C.P., 1986. Production, by filamentous, nitrogen-fixing cyanobacteria, of a bacteriocin and of other antibiotics that kill related strains. Arch. Microbiol. 145, 215-219.

Fujiki, H. Suganuma, M. 1993. Advances in Cancer Research. Tumor Promotion by Inhibitors of Protein Phosphatases 1 and 2A: The Okadaic Acid Class of Compounds, vol 61. Academic Press Inc, San Diego. 143-194.

Gallagher, S.R., Leonard, R.T., 1982. Effect of vanadate, molybdate, and azide on membrane associated ATPase and soluble phosphatase activities of corn roots. Plant Physiol. 70, 1335-1340.

Giner, J.L., Faraldos, J.A., Boyer, G.L., 2003. Novel sterols of the toxic dinoflagellate Karenia brevis (Dinophyceae): a defensive function for unusual marine sterols? J. Phycol. 39, 315-319.

Goldberg, J., Huang, H.B., Kwon, Y.G., Greengard, P., Nairn, A.C., Kuriyan, J., 1995. Three-dimensional structure of the catalytic subunit of protein serine/threonine phosphatase-1. Nature 376, 745-753.

Granéli, E., Hansen, P.J., 2006. Allelopathy in harmful microalgae: a mechanism to compete for resources? In: Granéli, E., Turner, J.T. (Eds.), Ecology of Harmful Algae. Springer-Verlag, Berlin, Heidelberg, pp. 189-201.

Grynkiewicz, G., Poenie, M., Tsien, R.Y., 1985. A new generation of $\mathrm{Ca}^{2+}$ indicators with greatly improved fluorescence properties. J. Biol. Chem. 260, 3340-3450.

Gusovsky, F., Yasumoto, T., Daly, J.W., 1989. Maitotoxin, a potent, general activator of phosphoinositide breakdown. FEBS Lett. 243, 307-312.

Hajnoczky, G., Csordas, G., Madesh, M., Pacher, P., 2000. Control of apoptosis by IP3 and ryanodine receptor driven calcium signals. Cell Calcium 28, 349-363.

Hansen, P.J., 1989. The red tide dinoflagellate Alexandrium tamarense: effects on behaviour and growth of a tintinnid ciliate. Mar. Ecol.-Prog. Ser. 53, 105-116.

Hansen, P.J., Cembella, A.D., Moestrup, Ø, 1992. The marine dinoflagellate Alexandrium ostenfeldii: Paralytic shellfish toxin concentration, composition, and toxicity to a tintinnid ciliate. J. Phycol. 28, 597-603.

Holmes, C.F.B., Boland, M.P., 1993. Inhibitors of protein phosphatase-1 and-2A two major serine-threonine phosphatases involved in cellular regulation. Curr. Opin. Struct. Biol. 3, 934-943.
Houdai, T., Matsuoka, S., Matsumori, N., Murata, M., 2004. Membranepermeabilizing activities of amphidinol 3, polyene-polyhydroxy antifungal from a marine dinoflagellate. Biochim. Biophys. Acta-Biomembr. 1667, 91-100.

Houdai, T., Matsuoka, S., Morsy, N., Matsumori, N., Satake, M., Murata, M., 2005. Hairpin conformation of amphidinols possibly accounting for potent membrane permeabilizing activities. Tetrahedron 61, 27952802.

Keating, K.I., 1977. Allelopathic influence on blue-green bloom sequence in a eutrophic lake. Science 196, 885-887.

Keller, M.D., Selvin, R.C., Claus, W., Guillard, R.R.L., 1987. Media for the culture of oceanic ultraphytoplankton. J. Phycol. 23, 633-638.

Klumpp, S., Krieglstein, J., 2002. Serine/threonine protein phosphatases in apoptosis. Curr. Opin. Pharmacol. 2, 458-462.

Knopik-Skrocka, A., Bielawski, J., 2002. The mechanism of the hemolytic activity of polyene antibiotics. Cell. Mol. Biol. Lett. 7, 31-48.

Köhler, T., Donner, V., van Delden, C., 2010. Lipopolysaccharide as shield and receptor for R-Pyocin-mediated killing in Pseudomonas aeruginosa. J. Bacteriol. 192, 1921-1928.

Konoki, K., Hashimoto, M., Murata, M., Tachibana, K., 1999. Maitotoxininduced calcium influx in erythrocyte ghosts and rat glioma C6 cells, and blockade by gangliosides and other membrane lipids. Chem. Res. Toxicol. 12 (10), 993-1001.

Kotlerbrajtburg, J., Medoff, G., Kobayashi, G.S., Boggs, S., Schlessinger, D., Pandey, C., Rinehart, K.L., 1979. Classification of polyene antibiotics according to chemical structure and biological effects. Antimicrob. Agents Chemother. 15, 716-722.

Kubanek, J., Hicks, M.K., Naar, J., Villareal, T.A., 2005. Does the red tide dinoflagellate Karenia brevis use allelopathy to outcompete other phytoplankton? Limnol. Oceanogr. 50, 883-895.

Leblond, J.D., Chapman, P.J., 2002. A survey of the sterol composition of the marine dinoflagellates Karenia brevis, Karenia mikimotoi, and Karlodinium micrum distribution of sterols within other members of the class Dinophyceae. J. Phycol. 38, 670-682.

Legrand, C., Rengefors, K., Fistarol, G.O., Granéli, E., 2003. Allelopathy in phytoplankton - Biochemical, ecological and evolutionary aspects. Phycologia 42, 406-419.

Ma, H., Krock, B., Tillmann, U., Cembella, A., 2009. Preliminary characterization of extracellular allelochemicals of the toxic marine dinoflagellate Alexandrium tamarense using a Rhodomonas salina bioassay. Marine Drugs 7, 497-522.

Mayor, S., Rao, M., 2004. Rafts: scale-dependent, active lipid organization at the cell surface. Traffic 5, 231-240.

Morrill, L.C., 1984. Ecdysis and the location of the plasma membrane in the dinoflagellate Heterocapsa niei. Protoplasma 119, 8-20.

Morsy, N., Houdai, T., Konoki, K., Matsumori, N., Oishi, T., Murata, M., 2008a. Effects of lipid constituents on membrane-permeabilizing activity of amphidinols. Bioorg. Med. Chem. 16, 3084-3090.

Morsy, N., Konoki, K., Houdai, T., Matsumori, N., Oishi, T., Murata, M., Aimoto, S., 2008b. Roles of integral protein in membrane permeabilization by amphidinols. Biochim. Biophys. Acta 1778, 14531459.

Murata, M., Gusovsky, F., Yasumoto, T., Daly, J.W., 1992. Selective stimulation of $\mathrm{Ca}^{2+}$ flux in cells by maitotoxin. Eur. J. Pharmacol.-Molec. Pharmacol. Sect. 227, 43-49.

Paul, G.K., Matsumori, N., Konoki, K., Murata, M., Tachibana, K., 1997. Chemical structures of amphidinol 5 and 6 isolated from marine dinoflagellate Amphidinium klebsii and their cholesterol-dependent membrane disruption. J. Mar. Biotechnol. 5, 124-128.

Paul, G.K., Matsumori, N., Konoki, K., Sasaki, M., Murata, M., Tachibana, K., 1996. Structure and membrane perturbation of amphidinol 3: strong antifungal metabolites produced by dinoflagellate, Amphidinium klebsii. In: Yasumoto, T., Oshima, Y., Fukuyo, Y. (Eds.), Harmful and Toxic Algal Blooms. Intergovernmental Oceanographic Commission of UNESCO, pp. 503-506.

Peeler, T.C., Stephenson, M.B., Einspahr, K.J., Thompson, G.A., 1989. Lipid characterization of an enriched plasma membrane fraction of Dunaliella salina grown in media of varying salinity. Plant Physiol. 89, 970976.

Pflugmacher, S., 2002. Possible allelopathic effects of cyanotoxins, with reference to microcystin-LR, in aquatic ecosystems. Environ. Toxicol. 17, 407-413.

Pinnaduwage, P., Bruce, B.D., 1996. In vitro interaction between achloroplast transit peptide and chloroplast outer envelope lipids is sequence-specific and lipid class dependent. J. Biol. Chem. 271, 32907-32915.

Piretti, M.V., Pagliuca, G., Boni, L., Pistocchi, R., Diamante, M., Gazzotti, T., 1997. Investigation of 4-methyl sterols from cultured dinoflagellate algal strains. J. Phycol. 33, 61-67. 
Rossini, G.P., 2000. Neoplastic activity of DSP toxins: the effects of okadaic acid and related compounds on cell proliferation: Tumor promotion or induction of apoptosis? In: Botana, L.M. (Ed.), Seafood and Freshwater Toxins. Marcel Dekker, New York, pp. 257-288.

Sivonen, K., Niemela, S.I., Niemi, R.M., Lepisto, L., Luoma, T.H., Rasanen, L. A., 1990. Toxic cyanobacteria (blue-green algae) in Finnish fresh and coastal waters. Hydrobiologia 190, 267-275.

Smith, P.K., Krohn, R.I., Hermanson, G.T., Mallia, A.K., Gartner, F.H., Provenzano, M.D., Fujimoto, E.K., Goeke, N.M., Olson, B.J., Klenk, D.C., 1985. Measurement of protein using bicinchoninic acid. Anal. Biochem. 150, 76-85.

Takahashi, M., Ohizumi, Y., Yasumoto, T., 1982. Maitotoxin, a Ca2+ channel activator candidate. J. Biol. Chem. 257 (13), 7287-7289.

Tergau, F., Weichert, J., Quentin, I., OpitzvonZezschwitz, R.C. vonZezschwitz, C., Marwitz, J., Ritz, V., Steinfelder, H.J., 1997. Inhibitors of ser/thr phosphatases 1 and $2 \mathrm{~A}$ induce apoptosis in pituitary GH(3) cells. Naunyn-Schmiedebergs Arch. Pharmacol. 356, 8-16.

Tillmann, U., Alpermann, T., John, U., Cembella, A., 2008a. Allelochemical interactions and short-term effects of the dinoflagellate Alexandrium on selected photoautotrophic and heterotrophic protists. Harmful Algae 7, 52-64.

Tillmann, U., Alpermann, T.L., da Purificação, R.C., Krock, B., Cembella, A.D. 2009. Intra-population clonal variability in allelochemical potency of the toxigenic dinoflagellate Alexandrium tamarense. Harmful Algae 8, 759-769.

Tillmann, U., Hansen, P.J., 2009. Allelopathic effects of Alexandrium tamarense on other algae: evidence from mixed growth experiments. Aquat. Microb. Ecol. 57, 101-112.

Tillmann, U., John, U., 2002. Toxic effects of Alexandrium spp. on heterotrophic dinoflagellates: an allelochemical defence mechanism independent of PSP-toxin content. Mar. Ecol.-Prog. Ser. 230, 47-58.
Tillmann, U., John, U., Cembella, A., 2007. On the allelochemical potency of the marine dinoflagellate Alexandrium ostenfeldii against heterotrophic and autotrophic protists. J. Plankton Res. 29, 527-543.

Tillmann, U., John, U., Krock, B., Cembella, A., 2008b. Allelopathic effects of bioactive compounds produced by harmful algae. In: Moestrup, Ø.e. a (Ed.), 12th International Conference on Harmful Algae. International Society for the Study of Harmful Algae and Intergovernmental Oceanographic Commission of UNESCO, Copenhagen, Denmark, pp. 12-18.

Van Wagoner, R.M., Deeds, J.R., Satake, M., Ribeiro, A.A., Place, A.R., Wright, J.L.C., 2008. Isolation and characterization of karlotoxin 1, a new amphipathic toxin from Karlodinium veneficum. Tetrahedron Lett. 49, 6457-6461.

Weinsberg, F., Bickmeyer, U., Wiegand, H., 1995. Effects of inorganic mercury $\left(\mathrm{HG}^{2+}\right)$ on calcium channel currents and catecholamine release of bovine chromaffin cells. Arch. Toxicol. 69, 191-196.

Windust, A.J., Quilliam, M.A., Wright, J.L.C., McLachlan, J.L., 1997. Comparative toxicity of the diarrhetic shellfish poisons, okadaic acid, okadaic acid diol-ester and dinophysistoxin-4, to the diatom Thalassiosira weissflogii. Toxicon 35, 1591-1603.

Windust, A.J., Wright, J.L.C., McLachlan, J.L., 1996. The effects of the diarrhetic shellfish poisoning toxins, okadaic acid and dinophysistoxin-1, on the growth of microalgae. Mar. Biol. 126, 19-25.

Yasumoto, T., Murata, M., Oshima, Y., Matsumoto, G.K., Clardy, J., 1984. Diarrhetic shellfish poisoning. ACS Symp. Ser. 262, 207-214.

Yasumoto, T., Oshima, Y., Yamaguchi, M., 1979. Occurrence of a new type shellfish poisoning in Japan and chemical properties of the toxin. In: Taylor, D.L., Seliger, H.H. (Eds.), Toxic Dinoflagellates Blooms. Elsevier, Amsterdam, pp. 495-502.

Yokoyama, A., Murata, M., Oshima, Y., Iwashita, T., Yasumoto, T., 1988. Some chemical properties of maitotoxin, a putative calcium channel agonist isolated from a marine dinoflagellate. J. Biochem. 104, 184-187. 